\title{
Development of Media-Based Learning Animation for Mathematics Courses in Electrical Engineering, University Riau Kepulauan
}

\author{
Kalbin Salim ${ }^{1}$, Dayang Hjh Tiawa ${ }^{2}$ \\ Department Mathematics and Multimedia Education, University Technology Malaysia ${ }^{1}$ \\ Department Sport Innovation Technology Centre, College, University Technology Malaysia ${ }^{2}$
}

\begin{abstract}
The purpose of this research is to develop instructional media based animations that have been validated, so that the media can be used in Subjects teaching Mathematics Engineering. Data obtained from a questionnaire given to media experts, the expert material, and 31 students of the 2nd half of 2013 class of the questionnaire Analyzed were using the method descriptive qualitative. According to media experts, the media is valid, so that the media can be used in learning, but with revisions. Matter Expert argue that the material is valid, so that this medium can be used. matter experts give advice as an improvement to perfection medium. based on the results test to 31 students who have tried this product, this media has been Invalid but with minor revisions.
\end{abstract}

Keywords: Development, Animation Media, Engineering Mathematics

\section{INTRODUCTION}

The Engineering Mathematics the core courses in the electrical engineering department which aims to provide an understanding and analysis of each course in electrical engineering. Based on observations and interviews with students of the previous 2010 and 2011 who have taken mathematics engineering courses during the learning process they still are passive receptive. This is caused by a lack of knowledge, reasoning and analytical problems in electrical engineering and a number of credits in mathematics courses were a little technique, which is only two credits per week. Therefore, it is required to always be creative in creating an atmosphere of learning, so that students will not feel bored and become motivated to learn mathematics concepts and analytical techniques such as the use of media such as animation and simulation is one of innovation and motivation given is through intermediaries relevant media in order to facilitate the delivery of content. Through the media, mathematics technique is expected to be received better. Contained in the learning barriers will be overcome with the use of instructional media, so that students will be able to receive the message better and make learning becomes a very attractive and effective. This is in accordance with the opinion of Sadiman et al [2], the media is anything that can be used to deliver a message from the sender to the receiver so that it can stimulate the thoughts, feelings, concerns and interests and attention of students such that the learning process occurs. Therefore, researchers suggest one alternative means of computer-based instructional media are different from ordinary media used by the teacher.

Media representative that researchers suggest is a mediaassisted animation Adobe Flash CS 6. Adobe Flash CS 6 is a vector-based animation program that is used to create animations and more professional applications such as animated logos, cartoons, games, interactive menus and multimedia applications [1]. By using this program a lot of benefits that can be taken including banners, advertising, slide presentations, CD-opening, games, cartoons, learning projects, and greeting cards (e-cards).

Excess of Adobe Flash when compared to other software: (1) able to create an interactive button with a movie or other objects,

(2) Adobe flash capable of making color transparencies in the movie,

(3) Adobe Flash is able to make changes to the animation of the form into another form and is capable of making motion animation by following a predetermined path,

(4) file can be converted and published to the application files (exe),

(5) tools provided more varied. Based on the explanation above, the developer intends to develop a product-based learning media-assisted animation in Adobe Flash CS 6 Mathematics learning technique.

Media is expected to attract the interest and motivation of students in learning Mathematics Engineering. In addition, it is expected that the media can help students overcome the difficulties in analyzing problems and understanding concepts of Engineering Mathematics [4].

Engineering Mathematics learning so become more active and effective. Therefore, from the description above, the researchers took the title "Development of Media-Based Learning animation for Mathematics Courses in Electrical Engineering, University Riau Kepulauan".

\section{Method}

The method used by the researchers is a method of research and development (research and development). Procedures in the development of this research modifies the development model of Borg and Gall with the steps of Sugiyono [4],[5].

www.ijarcce.com 8332 
Researchers took 5 steps in the development of multimedia learning with Adobe Flash CS 6 on Engineering Mathematics courses with the steps shown in Fig. 1 below:

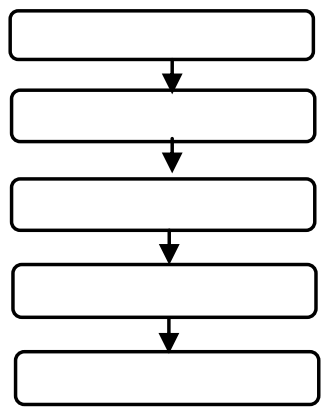

Fig 1. Step-by-step procedure development

The data in this study was obtained from a questionnaire given to the test subjects, the media expert, the expert material, and 31 4th semester student of class 2012 who has followed the course of Engineering Mathematics. Results from the questionnaire were analyzed using qualitative descriptive approach.

\section{III.RESULTS}

Data obtained from the results of this development comes from a questionnaire given to the three test subjects, namely: media experts, material experts, and students of electrical engineering class of 2012 half 4 . The description is as follows.

\section{A. Data Expert Media}

Animation-based instructional media products have been tested for feasibility by Pamor Gunoto, MT as a media expert validator. Validator assess the entire look of the media contained in the animation-based learning courses for students of Engineering Mathematics 2012 semesters 4 In addition, the quality of video, audio, images, and animations are also assessed by the validator. Media validation performed on February 1, 2013 The results of the validation are clearly presented in the following table: entire document should be in Times New Roman or Times font. Type 3 fonts must not be used. Other font types may be used if needed for special purposes. Recommended font sizes are shown in Table 1.

\section{B. Title and Author Details}

Based on the table above her questionnaire validation, it is known that the amount of $\mathrm{P}$ (percentage of the overall data) is $75 \%$, so that the animation-based instructional media on Engineering Mathematics courses are valid and can be used in learning with little revision.

\section{Matter Expert Data}

Matter experts who becomes validator for testing products based learning media animation is toni kusuma wijaya, m.si. The results of the validation of the validator material presented in table 4.2. The material on this animated media
TABLE I

EXPERT MEDIA QUESTIONNAIRE RESULTS

\begin{tabular}{|c|c|c|c|c|c|c|c|c|}
\hline No & Statement & SA & $\mathbf{A}$ & $\mathbf{D}$ & SD & $\mathbf{X}$ & $\mathbf{X} \mathbf{i}$ & $\%$ \\
\hline 1 & $\begin{array}{l}\text { Interesting front page } \\
\text { display }\end{array}$ & & $\sqrt{ }$ & & & 3 & 4 & $75 \%$ \\
\hline 2 & $\begin{array}{l}\text { Font size used in } \\
\text { each page is clear and } \\
\text { easy to read }\end{array}$ & & $\sqrt{ }$ & & & 3 & 4 & $75 \%$ \\
\hline 3 & $\begin{array}{l}\text { Neat layout and } \\
\text { typing }\end{array}$ & & $\sqrt{ }$ & & & 3 & 4 & $75 \%$ \\
\hline 4 & $\begin{array}{l}\text { Suitability laying the } \\
\text { menus in the display } \\
\text { media }\end{array}$ & & & $\sqrt{ }$ & & 2 & 4 & $50 \%$ \\
\hline 5 & $\begin{array}{l}\text { Images and colors } \\
\text { contained in this } \\
\text { media interesting }\end{array}$ & & & $\sqrt{ }$ & & 2 & 4 & $50 \%$ \\
\hline 6 & $\begin{array}{l}\text { The music is } \\
\text { presented interesting } \\
\text { and not interfere with } \\
\text { the process of media } \\
\text { use }\end{array}$ & & $\sqrt{ }$ & & & 3 & 4 & $75 \%$ \\
\hline 7 & $\begin{array}{l}\text { Instructions for use of } \\
\text { media is easy to } \\
\text { understand }\end{array}$ & & $\sqrt{ }$ & & & 3 & 4 & $75 \%$ \\
\hline 8 & $\begin{array}{l}\text { The quality of the } \\
\text { navigation buttons in } \\
\text { the media quite good }\end{array}$ & & $\sqrt{ }$ & & & 3 & 4 & $75 \%$ \\
\hline 9 & $\begin{array}{l}\text { Conformity with the } \\
\text { media design } \\
\text { learning materials }\end{array}$ & & $\sqrt{ }$ & & & 3 & 4 & $75 \%$ \\
\hline 10 & $\begin{array}{l}\text { Suitability of the } \\
\text { material in the media } \\
\text { of animation }\end{array}$ & & $\sqrt{ }$ & & & 3 & 4 & $75 \%$ \\
\hline 11 & $\begin{array}{l}\text { Easy to operate this } \\
\text { media }\end{array}$ & & $\sqrt{ }$ & & & 3 & 4 & $75 \%$ \\
\hline 12 & $\begin{array}{l}\text { Media exposure in } \\
\text { this great animation }\end{array}$ & & $\sqrt{ }$ & & & 3 & 4 & $75 \%$ \\
\hline 13 & $\begin{array}{l}\text { Developed an } \\
\text { effective medium for } \\
\text { activities Learning }\end{array}$ & $\sqrt{ }$ & & & & 4 & 4 & $100 \%$ \\
\hline 14 & $\begin{array}{l}\text { This media is able to } \\
\text { attract the interest } \\
\text { and motivation } \\
\text { student }\end{array}$ & $\sqrt{ }$ & & & & 4 & 4 & $100 \%$ \\
\hline 15 & $\begin{array}{l}\text { This media is } \\
\text { interesting as a whole }\end{array}$ & & $\sqrt{ }$ & & & 3 & & $75 \%$ \\
\hline & $\Sigma X$ & & & & & 45 & & \\
\hline & $\Sigma X i$ & & & & & & 60 & \\
\hline & $P$ & & & & & & & $75 \%$ \\
\hline
\end{tabular}

assessed on January 23, 2014 Rating material on this media include completeness of information on topics integral and differential, animation and audio conformance with the material, and the suitability of exercises.

Based on the questionnaire validation table matter experts in table 4.2 below, it can be seen that the amount of $\mathrm{P}$ (percentage of the overall data) is $85 \%$, so that the animation-based instructional media on Engineering Mathematics courses are valid and can be used in learning with little revision.

\section{Data of Students}

Data are students 4th semester students of 2012 who have tried media-based learning animation. The number of students in the study were already using the medium of animation is 31 people. Student test phase was conducted on February 3, 2014. Provide an assessment of student 
learning media products and materials that the overall number of statements contained 15 items. The description of the results of the pilot questionnaire to 2012 students of 4th semester.

TABLE 2

MATTER EXPERT DATA

\begin{tabular}{|c|c|c|c|c|c|c|c|c|}
\hline No. & Statement & SA & $\mathbf{A}$ & $\mathbf{D}$ & SD & $\mathbf{X}$ & $\mathbf{X}$ & $\%$ \\
\hline 1 & $\begin{array}{l}\text { The language used is simple } \\
\text { and easy to understand }\end{array}$ & & $\sqrt{ }$ & & & 3 & 4 & $75 \%$ \\
\hline 2 & Fill a clear learning materials & & $\sqrt{ }$ & & & 3 & 4 & $75 \%$ \\
\hline 3 & $\begin{array}{l}\text { The material contained in this } \\
\text { medium is appropriate in the } \\
\text { achievement of learning } \\
\text { objectives }\end{array}$ & $\sqrt{ }$ & & & & 4 & 4 & $100 \%$ \\
\hline 4 & $\begin{array}{l}\text { Instructions on filling in a } \\
\text { matter of obvious }\end{array}$ & & & $\sqrt{ }$ & & 3 & 4 & $75 \%$ \\
\hline 5 & $\begin{array}{l}\text { Exercises in accordance with } \\
\text { discourse in material }\end{array}$ & $\sqrt{ }$ & & & & 4 & 4 & $75 \%$ \\
\hline 6 & $\begin{array}{l}\text { The language used in the } \\
\text { exercises easily understood by } \\
\text { students }\end{array}$ & & $\sqrt{ }$ & & & 3 & 4 & $75 \%$ \\
\hline 7 & $\begin{array}{l}\text { Provision of questions and level } \\
\text { of difficulty was appropriate } \\
\text { exercises }\end{array}$ & & & $\sqrt{ }$ & & 2 & 4 & $50 \%$ \\
\hline 8 & $\begin{array}{l}\text { Animations that help in } \\
\text { mastering the material } \\
\text { presented }\end{array}$ & & $\sqrt{ }$ & & & 3 & 4 & $75 \%$ \\
\hline 9 & $\begin{array}{l}\text { Animation contained in this } \\
\text { media in accordance with the } \\
\text { material }\end{array}$ & $\sqrt{ }$ & & & & 4 & 4 & $100 \%$ \\
\hline 10 & $\begin{array}{l}\text { The videos are contained in this } \\
\text { medium in accordance with the } \\
\text { material }\end{array}$ & & $\sqrt{ }$ & & & 3 & 4 & $75 \%$ \\
\hline 11 & $\begin{array}{l}\text { Object images available in this } \\
\text { medium in accordance with the } \\
\text { material }\end{array}$ & $\sqrt{ }$ & & & & 4 & 4 & $100 \%$ \\
\hline 12 & $\begin{array}{l}\text { The material contained in this } \\
\text { media is complete }\end{array}$ & & $\sqrt{ }$ & & & 3 & 4 & $75 \%$ \\
\hline 13 & $\begin{array}{l}\text { The material contained in this } \\
\text { media clearly }\end{array}$ & & $\sqrt{ }$ & & & 3 & 4 & $75 \%$ \\
\hline 14 & $\begin{array}{l}\text { Learning to use this medium to } \\
\text { be effective }\end{array}$ & & $\sqrt{ }$ & & & 3 & 4 & $75 \%$ \\
\hline 15 & $\begin{array}{l}\text { This media is interesting as a } \\
\text { whole }\end{array}$ & $\sqrt{ }$ & & & & 4 & 4 & $100 \%$ \\
\hline & $\Sigma X$ & & & & & 51 & & \\
\hline & $\Sigma X i$ & & & & & & $\begin{array}{l}6 \\
0 \\
\end{array}$ & \\
\hline & $P$ & & & & & & & $85 \%$ \\
\hline
\end{tabular}

Based on the student questionnaire table above, it can be seen that the amount of $\mathrm{P}$ (percentage of the overall data) is $77.47 \%$, so that the animation-based instructional media on Engineering Mathematics courses are valid and can be used in learning with little revision.

\section{IV.DISCUSSION}

\section{A. Data Analysis of Expert Medias}

Based on the results obtained from the questionnaires media experts can be seen that of the total number of items in the questionnaire, as many as 15 points, 2 points to answer media experts strongly agree with the answer. This point is a point 13; Developed an effective medium for learning activities and clause 14; This media is able to attract the interest and motivation of students.

Copyright to IJARCCE

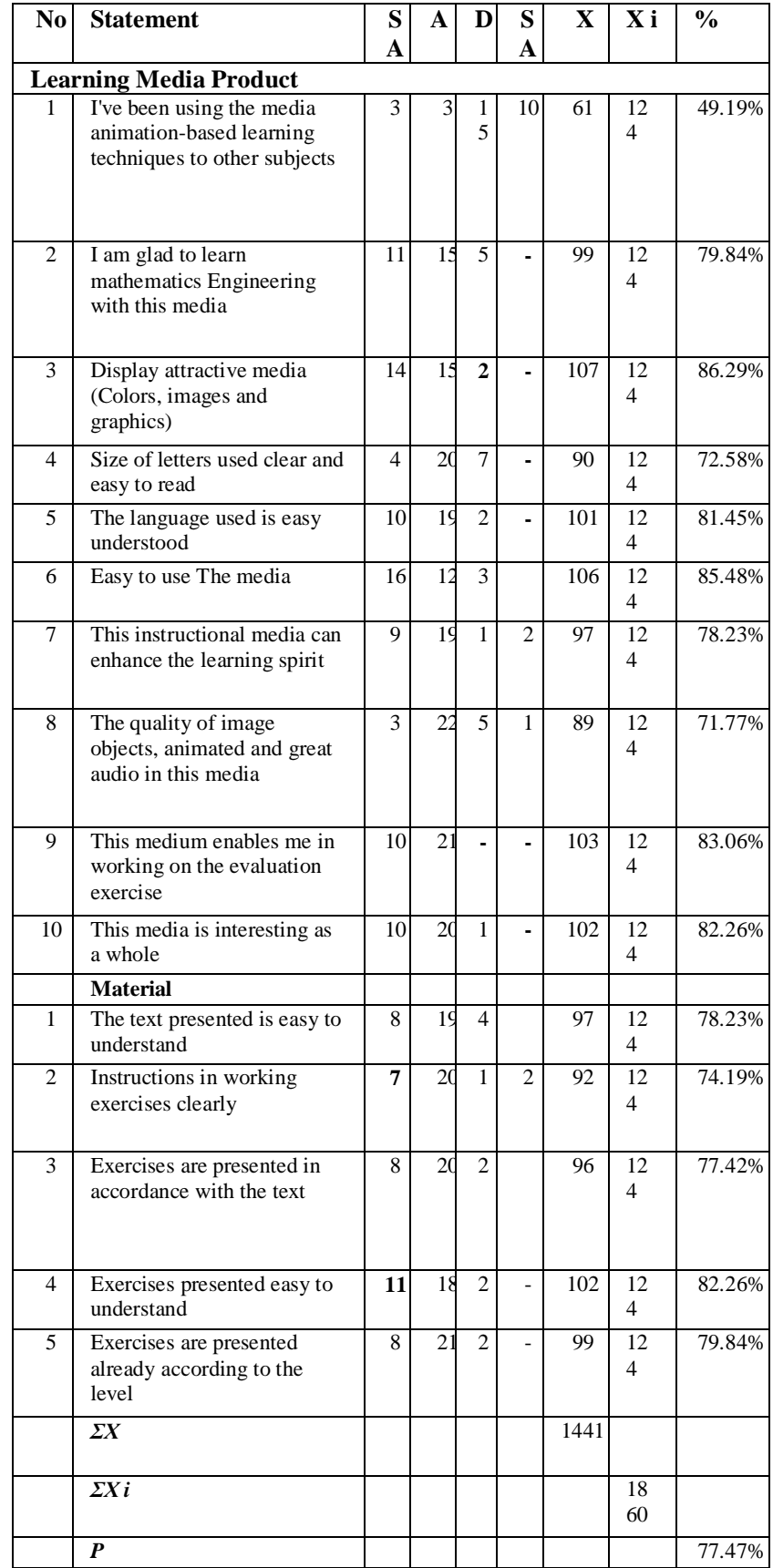

TABLE 3 RESULT OF STUDENT QUESTIONNAIRE

Number of responses agreed from the results of the questionnaire is 11 grains. As these points, among others: (1) display interesting front page (2) The size of the letters used in each page is clear and easy to read, (3) typing layout and neat, (6) Music presented interesting and do not interfere with the use of the media, (7) Instructions for use of media is easy to understand, (8 ) The quality of the navigation buttons in the media is good, (9) Compliance with the media design learning materials, (10) Conformity animation of the material in the media, (11) Easy to operate this medium, (12) Exposure nice animation in the media, (15) This media is interesting as a whole.

While media experts agree less answer 2 points, namely, item 4 on the suitability of the layout of the menu in the display media and point 5 of neighbor exposure image www.ijarcce.com 
exposure and color less harmonious, and this is what will be done for the next repair.

The results of the analysis based on questionnaire sheets, suggestions, criticisms, and comments obtained from media experts, it can be concluded that the lack of media experts agree on the layout and appearance of the material contained on the media because it is still neat. In addition, also the problem of famine images and colors that are less harmonious and necessary adjustments for each background color so that exposure to more interesting animations.

In addition, experts also suggest the use of the media is more effective and has all the functions and links in accordance with the instructions for use of animation. Based on the results of the overall analysis, we can conclude that the animation-based instructional media course on Engineering Mathematics 2012 4th semester students of Electrical Engineering Department of the University of Riau Islands is feasible to be used as a medium of learning with some revisions and the deficiencies which have been described already fixed accordance with the advice given by media experts.

\section{B. Matter Expert Data Analysis}

Based on the results obtained from the questionnaires matter experts, it can be seen that of the total number of items in the questionnaire, as many as 15 points, 5 points matter experts answering strongly agree with the answer.

These five points are as follows: (1) The material contained in this medium is appropriate in the achievement of learning objectives, (2) Problem of exercise in accordance with the discourse in the material, (3) Animation contained in this media in accordance with the material, (4) object images available in this medium in accordance with the material, and (5) The media is interesting as a whole.

Matter experts to answer 8 items with answers agree. The eight points are as follows: (1) The language used is simple and easy to understand, (2) Fill clear learning material, (3) The language used in the exercises easily understood by students, (4) Animation presented helps in mastering material, (5) Video contained in this media in accordance with the material, (6) The material contained in this media is complete, (7) The material contained in this medium is clear and (8) Learning to use this medium to be effective.

Matter experts answer as many as 2 points less agrees with the answer.

As these items is item 4 and item 7 as follows.

a. Clear instructions about charging.

b. Provision of questions and level of difficulty was appropriate exercises

Based on the results of the questionnaire analysis validator matter expert, Toni Kusuma Wijaya, Music. stating that the material contained in this medium is valid in terms of content, but in terms of language and instructions still need to be repaired because of the language contained in this media still difficult to understand. In addition there are errors in the written language and understanding of the material of video images and animated images.
The suggestions put forward by the validator matter experts, namely on each question contained in the website should be back training on a single number if the answer is wrong, so students or media users do not need to repeat from the beginning or completing all of the exercises. Animation should be briefed in Indonesian and clearly written source material in detail. Developers are also advised to provide guidance in filling exercises. In addition, the images should be included in the official media.

At the time validator assessing material contained in this media, ask why not all the validators in the media sessions are animated and why there are no control buttons for the animation. Developers in developing these media are still many shortcomings reference source, especially for searching for related animations that match the description of each session, so that not all sessions are animated. Button control contained in the animation sometimes can't arise because not all computers or laptops have the flash player software. Therefore, suggestions, criticisms and comments given by the validator used as reference in the material improvement in the media, but on the whole this is feasible media used in the study with some revisions to the deficiencies-lack of which has been described above.

\section{Data Analysis of Student}

Data from the entire 4th semester students of Electrical Engineering class of 2012 is 31 students obtained from a questionnaire consisting of 15 items, ie 10 points for instructional media products and 5 points for the material. This questionnaire aims to determine whether the student has previously been used for media-based learning courses animation techniques or not, that is the question number 1 media products and also to know the opinion of students on instructional media products, the numbers $2-10$ and the material in in the media, the numbers 1-5. The explanation of the results of the questionnaire are as follows. Question number 1 on the products of learning media is to determine whether the student has been using the medium of animation-based learning for engineering courses or not. The result is as many as 10 students answered disagree and 15 students answered less agree. The students who answered strongly agree is as much as 3 students and 3 students answered agree. Therefore, it can be concluded that more than half of the students had never used a mediabased learning animation for engineering courses. The next question is to determine student opinion about teaching media products that have been developed. 11 students expressed strongly agreed and 15 students agreed that they enjoy learning Mathematics Engineering with this learning medium.

There are only 5 students expressed less agree that the student is less happy to learn Mathematics Engineering with this medium. In question number 3, 14 students answered strongly agree and 15 students answered agree that the media display attractive in terms of color, images, and graphics. While students who answered disagree as much as 2 students. Students who answered strongly agree that the font size used clear and easy to read as much as 4 students and students who answered agree is 20 students. 7 
students disagree with the statement on number 4 , that the size of the font used is clear and easy to read. There are 10 students who strongly agreed, 19 students who answered agree, and 2 students who answered less agree on the statement number 5 that the language used is easy to understand. Statement number 6 which states that the media is very easy in use agreed to answer as many as 16 students, 12 students agreed, and the three students who expressed less agree.

Statement number 7 which states that instructional media can enhance students' learning spirit of strongly agree answer by 9 students. 19 students agreed, 1 student does not agree, and 2 students do not agree. Statement number 8 on the quality of the object image, video and audio in the media stating there are 5 students strongly agreed (very good), 26 students agreed (good), 10 students agreed less (normal), and 1 student disagree (bad). The next statement, the statement number 9 , as many as 10 students strongly agreed and 21 students agreed that learning media is easier for students in working on the evaluation exercise. The last statement about the product media that students expressed the opinion that the media is interesting as a whole answered very agree as many as 10 students, 20 students agreed, and that states disagree as much as 1 students. In the statement number 1 on the material contained in the instructional media, 8 students argued strongly agreed that the text presented is easy to understand. 19 students and 4 students agreed that states disagree. Furthermore, 7 students strongly agreed that the instructions clearly doing exercises and 20 students agreed.

While students who disagree with the statement contained 1 student and 2 students disagree. In the statement number 3,8 students expressed strongly agree and 20 students agreed that the exercises are presented in accordance with the text. There are 2 students expressed less agree with the statement. Students who expressed strongly agreed that the exercises presented is easy to understand and the 11 students who agree there are 18 students. While students who expressed less agree there are 2 students. The statement is a statement of the number 4 last statement of the material there are 8 students who strongly agreed that the training has been presented in accordance with the levels. 21 students and 2 students agreed less agree.

The results of student questionnaire data analysis above shows that more than half of the 4th semester student of class 2012 who are already using media-based instructional animations in Engineering Mathematics courses states that instructional media product is nice and interesting to use in the learning process of Engineering Mathematics.

However, there are some suggestions and criticism of students that must be considered, including the following: (1) The initial view that the media made much more memorable for motivating students to learn mathematics in engineering, (2) Layout background better if made with bright colors so it will be more interesting, (3) material needs to be added up to one semester because the media is only material for only a few topics, (3) Images and animation need to be added in a few sessions because there are no images and animations.

In addition there is a lack of good animation and size, yet sufficient, (4) animation should be given for each title in order to assist in facilitating and understanding the contents of the animation display, (5) It would be nice if the exercises, if when the wrong answer and the answer can be directly known but still continues to proceed to the next number.

It also needs to be multiplied exercises, and (6) The size of the letters need to be adjusted to make it more attractive and easy to understand with clear material and so each session can increase student motivation to learn math techniques.

\section{Conclusion}

The resulting product has been tested and revised so that it is feasible to use the media to learning Engineering Mathematics. Revision of the results obtained based on the analysis of a questionnaire given to media experts, the expert material, and a student of class 31 in 2012 semesters 4 Based on the analysis results, indicate that the animation-based instructional media is fit for use as a medium of learning in Engineering Mathematics courses. Suggestions for further research are advanced researchers can develop the material in the media until the material for one semester, because of the material contained in this media are just a few subjects. In addition, developers are advised to develop animated media on Mathematics learning techniques that are online to be accessed through the internet.

\section{REFERENCES}

[1] Candra. 2006. Flash Professional 8 untuk Orang Awam. Jakarta: Maxindo

[2] Sadiman, A. S., Rahardjo, R., Haryono, A., Rahardjito. 2002. Media Pendidikan,Pengertian, Pengembangan dan Pemanfaatannya. Jakarta: PT Raja Grafindo Persada.

[3] Kreyszig, E. (2007). Advanced engineering mathematics. John Wiley \& Sons.

[4] Sugiyono. 2010. Metode Penelitian Pendidikan (Pendekatan Kualitatif, Kuantitatif, dan $R \& D)$.Bandung: Alfabeta

[5] Sukmadinata, N. S. 2009. Metode Penelitian Pendidikan.Bandung: PT Remaja Rosdakarya Offset. 